\title{
A Historical Synopsis of Over-feminized Local Governance in Neoliberal Turkey
}

\section{Sezen Yaraş}

To cite this article: Sezen Yaraș (2014) A Historical Synopsis of Over-feminized Local Governance in Neoliberal Turkey, Turkish Studies, 15:1, 100-116, DOI: 10.1080/14683849.2014.892239

To link to this article: http://dx.doi.org/10.1080/14683849.2014.892239

曲 Published online: 31 Mar 2014.

Submit your article to this journal $\pi$

Lll Article views: 230

Q View related articles $\asymp$

View Crossmark data $\asymp$ 


\title{
A Historical Synopsis of Over-feminized Local Governance in Neoliberal Turkey
}

\author{
SEZEN YARAȘ \\ Department of Political Science and Public Administration, Bilkent University, Ankara, Turkey
}

\begin{abstract}
In Turkey, important decentralization measures were taken after the 1980s. The new administrative model gave local governments the role of dealing with social exclusion while financing social welfare expenditures through entrepreneurial investment of their nonmaterial resources. This study is an attempt to discuss how such a challenge for local governments has been resolved through the analysis of gendering impacts of three decentralization reform programs.
\end{abstract}

\section{Introduction}

The literature on the relationship between gender and state presents local governments as a particular realm of study due to the emphasis on their distinct role in providing more and variant participatory channels for women, compared to national-level politics. Due to local governmental institutions being more spatially accessible, it is argued that they are better at motivating more women to play active roles, for resolving the gendered democratic deficit and hence more genderaware distribution of resources. ${ }^{1}$ As stressed by Alkan, "indicators offered by available international statistical data and observations of many researchers point out that women's formal political involvement at the local level is stronger than that at the national level for the majority of states." ${ }^{2}$ Therefore, the argument follows that decentralization is beneficial for increasing women's active engagement in politics and hence functional in terms of resolving gendered inequalities by increasing the number of women politicians.

However, this idealized definition of local governments does not allow the analysis of structural and functional differences among local governments themselves in different historical periods or from one country to another. Decentralization is not a uniform experience and the forces and legitimacy structures behind institutionalization are open to spatiotemporal reading. In other words, it might be helpful to make a distinction between two ways of using the term "decentralization," which are

Correspondence Address: Sezen Yaraş, Department of Political Science and Public Administration, Bilkent University, 06800 Bilkent, Ankara, Turkey. Email: yaras@ bilkent.edu.tr 
decentralization as an ideology and decentralization as a process of administrative and legislative reform.

Decentralization as an ideology refers to an ahistorical definition of local governments that is idealized in terms of its bringing about increased control of local actors on the decision making mechanisms and enabling direct participation of citizens. Local governments are argued to be critical actors in both coordinating the participation of different local groups as well as increasing the participatory capacities of different stakeholders that will be influenced by these decisions. Thus, rather than being institutions that implement the decisions taken at the central level, with decentralization, the local governments' sources of legitimacy shift to representation of local interests and the possibility of high pressure of local politicians for keeping them more accountable. Therefore, decentralization is argued to be functional in opening up various channels of participation in order to hold the local governments more accountable "downwards" rather than "upwards." 3 Decentralization as a process of administrative reform, on the other hand, does not have a universal form and which groups have "local actor" status and how their status as such is legitimized differs from one spatiotemporal context to another.

If decentralization is analyzed through its second usage, the contextual variables and how the strategy of local governance is discursively framed in the decentralization policies in a given time become the material of analysis for studying its impact in terms of women's substantive representation. "Nearly all countries worldwide are now experimenting with decentralization... seen as a solution to many different kinds of problems." ${ }^{4}$ Rather than analyzing the issue of female representation at the local level as a separate realm of analysis, how it is framed in interaction with these various problems in different contexts might introduce a distinct framework to discuss gender-specific characteristics of decentralization.

One common problematic discussed in examples from different decentralization processes within the context of neoliberal transformations is social policy and social inclusion-related challenges for local governments in welfare state retrenchment. Increased social inclusion roles of municipalities as a policy response to these challenges have been discussed through the analysis of various cases. ${ }^{5}$ Another common problematic in the contexts of neoliberal decentralization is the new entrepreneurial characteristics of the cities and restructuring of local governments for their developing strategic plans that will promote economic growth and competitiveness at the local level. ${ }^{6}$ How different versions of dealing with these two challenges in different spatiotemporal contexts affect and are affected by the gendered dynamics of their distinct socioeconomic environment might suggest deepening of discussions about female representation in local governments. Different strategies of dealing with these challenges, various versions of strategic partnership between public, private and informal groups and how these strategies interact with the "spatial specificity of gender relations", introduce a distinct material to discuss various gendered dynamics of decentralization processes. This kind of conceptualization of decentralization "does not 'fix' the who, where, when and how of substantive representation of women in advance but traces over time the critical actors, sites and 
dynamics in context." ${ }^{8}$ This study is an attempt to make use of the analytical tools of such perspective of decentralization to analyze the gender-related dynamics of three decentralization reform periods in Turkey since the 1980s. ${ }^{9}$

\section{Engendering Decentralization Reforms in Neoliberal Turkey}

One of the most important aims of decentralization in the 1980s' Turkey was to deal with the challenges of rapid urbanization that characterized the period after economic liberalization. In Bugra's words, "It is the objective of controlling the rapidly accelerating expansion of gecekondu (squatter areas) that forms the rationale behind the extended powers of municipal governments." ${ }^{.0}$ Therefore, in Turkey, the crisis of social inclusion and social reproduction in the urban context corresponds to an increasing policy-related interest in the administrative reforms about decentralization and restructuring of local governments.

The resources given to local governments during these reform periods are mostly non-material, such as the right to urban planning, right to privatize the municipal services or selective application of the regulations. Hence, another challenge for the local governments is to generate their own resources for the local governmental services in the context of "deregulation, non-public budget administrative units and privatization."11 A parallel reading of the economic programs and the social inclusion programs of the decentralization reforms of 1984, 1994 and 2004 reveals that the municipal economic planning strategies have been framed as investment on urban land, local capital and urban regeneration, respectively.

The first redistribution and social inclusion program was based on amnesty law for squatters to resolve not only their housing needs but also benefit from the increasing exchange value of urban land. Thus, the problem of social inclusion was defined in terms of the socioeconomic conditions of the squatter areas and the redistribution of their share from the urban rent within this group was left to the solidarity relations among themselves. In the second period, the question of social inclusion was planned to be resolved through local actors of social assistance and the reproduction of local solidarity ties as a moral entity. Finally the social inclusion discourse in the third period was based on empowering the "human capital."

In all the strategies, the reproduction of these social inclusion mechanisms was conducted by women as the reproducers of solidarity ties among the squatters, and the builders of social safety and social assistance networks. Female participation in these systems of local governance has been a derivative of the social inclusion discourses embedded in the local economic development programs. When the local governments and the decentralization reforms are contextualized as such, it is possible to argue that the gendered dynamics of local governments is more complex than the physical presence or absence of women in local governmental decision-making mechanisms. When women's representation is reduced to their role in social reproduction the content of which has been predetermined, their access to local governments "requires obedience, tribute and contribution, and can thus be a "claustrophobic game'." 12 In this study, the gendered implications of the three 
terms of decentralization in Turkey, in 1984, 1994 and 2004, are discussed in terms of such claustrophobic implications for women and what this might be suggesting for the feminist methodology of research on gender and local politics.

\section{The 1980s: Post-industrial Urban Governance and Women as Reproducers of Solidarity}

In the scholarly literature about local governments in Turkey, the decentralization reform package of 1984 is usually referred as a turning point. First, with these reforms, local governments were no longer only responsible for implementing decisions taken by central governments but were equipped with certain rights regarding the governing of the city space. Second, these reforms were important in introducing a different approach to the question of immigration and social inclusion in the urban context. In the previous local governmental policies, the main problematic about governing the city had mostly been defined as "over-urbanization"13 or "fast depeasantization and slow worker-ization," referring to the cities growing faster than their industrial bases. ${ }^{14}$ Hence, the question of increasing urbanization and squatter housing's being the main housing strategy of the immigrants were seen as issues to be resolved with increased economic development.

The "new" urban dwellers became the focus of interest for Turkish local politicians in terms of their housing and working conditions. Squatter housing (Gecekondulaşma) was the main term defining the former and the "growing informal sector" as well as the "cheap and flexible labor with no social security" defining the latter. The squatters were depicted as an oppressed, disadvantaged social group and the local governments were attributed a "father" role. ${ }^{15}$ At this "transition" stage, the informal ties of reciprocity and solidarity at the gecekondu areas were functional for preventing social unrest. Townsmen (hemşehri) networks that were founded upon sentiments of coming from the same place were very functional in terms of "facilitating cooperation and solidarity among the emigrants of the same locality during the settlement of the new inhabitants in large cities."16

The perception about these squatter areas' temporary status ended with the amnesty law of 1984 that was part of a bigger decentralization reform package. With that package, local governments were granted significant non-material resources, such as "selective implementation of their regulatory powers particularly in the areas of urban planning, the issuing of construction licenses, and the enforcement of zoning and building codes." ${ }^{17}$ In order to analyze the significance of these resources, it should be noted that it was the period of economic liberalization and deregulation that had a direct impact on the socioeconomic structure of the city space.

After the implementation of open market rules, the big cities where industrial centers were located started to be transformed. Big industries at the center of the cities were replaced with more foreign capital-attracting sectors. As Erkip indicates, in Turkey "industry has left the urban core since 1980s due to high land prices and the state incentives given to the adjacent cities to decentralize industry." 18 At this time of urban transformation and increased competition for urban land, the amnesty law "did 
not only legalize the illegally built squatter houses but also allowed the owners to add a maximum of four storeys to their buildings."19

When gecekondu areas were legalized, infrastructural investments meant increased exchange value of squatter houses at a time when the exchange value of urban land itself was increasing. Thus, distributing the urban rent to these groups as an income source was targeted to compensate for the lack of industrial development. Such way of managing immigrants' economic and social conditions was supposed to be transitory, meaning the institutionalization of a particular form of interaction between local political authorities and the squatter inhabitants.

Rather than being seen as temporary groupings, political parties started negotiating with notables of hometown groupings and organizations; and they started being nominated and elected for municipality councils. In other words, within this decentralization program, rather than being the objects of concerns about urban unrest, they were framed as the subjects that represented the interests of their communities. The political parties started to "prefer candidates originating from regions strongly represented amongst non-indigenous city inhabitants." 20 Thus, it can be argued that the local governments were exchanging their non-material resources with the provision of social welfare in these solidarity groupings. Therefore, the decentralization process in the 1980s in a way functioned to give informal networking ties a kind of formal role as local actors.

The new strategy of urban planning and social inclusion consisted of the networking of the local politicians with the gecekondu "notables" and their social solidarity ties. Although the amnesty law is usually analyzed in the framework of clientelism and short-term populist policies in exchange for votes, this type of decentralization was useful for decreasing the cost of social expenditure. In other words, this can also be studied as a distinct way of "embedding" the neoliberal transformations through the new decentralization policies by subcontracting the provision of social services and redistribution to the immigrants' solidarity networks mostly based on coming from the same hometown.

As White indicates, the strong ties of redistribution among the relatives, people immigrating to the city from the same hometown and neighbors provide a very significant source of social welfare. ${ }^{21}$ Thus, it can be argued that affirming the informal ties of social welfare was functioning as the social policy of the local governments. Thus, decentralization reform program consisted of the implementation of the amnesty law and resolving the economic problems of the immigrant by giving them a share from the urban rent. In other words, "the distribution of high urban land and real estate rents among various segments of the society as a redistribution strategy, the urbanization process was financed and the immense problems of urbanization were planned to be resolved." 22

As far as the gendered implications of this type of decentralization is concerned, the representation of the hometown-based informal groups as a "black box" or as an individual in itself ${ }^{23}$ was far from leading to introduction of gender-aware policies and increasing women's active participation. Such an exchange between local governments and former "informal" new "local actors" gave women's role in the 
reproduction of these solidarity ties a new status. Since it was these solidarity groups that were represented as a whole, local governments' strategy of social reproduction or redistribution in this period is based on the affirmation of the redistributive relations and survival strategies within these groups.

The reproduction of the community-based social ties and the social safety net through the mutual aid mechanism within these ties is a gendered process in the sense that the daily reproduction of the community networks through intimate contacts with the group members such as communal care for the children, elderly and sick as well as reproducing the rituals of the "hometown" is performed by women. Especially under the conditions of deregulation and decreasing social expenditure, these hometown- or kinship-based communities made it possible for these group members to not only survive but also "gradual establishment of land rights, finding regular cash employment, securing their children's education, providing their children with houses and reaching a moderate level of well-being." 24 Thus, the redistribution of the income among the community members and the social reproduction of these communal ties, which were conducted by the women members of these groups, served as the social welfare provision mechanism in this system of urban management.

It can be argued that the system of local governance was based on gendered division of labor; men networking with local governors in order to have a share in the distribution of resources and women networking among relatives and hometownbased groupings to reproduce relations of redistribution. Hence, the implementation of the decentralization policies fixed women's role as reproducers of community ties. Women had already been performing these roles before the reforms; however, the local governments cooperating with these informal groupings limited them to these roles only. Women could be elected as local politicians due to the gendered characteristics of the political capital. Also, their access to these institutions could take place only in terms of demanding certain benefits for the family and community. Therefore, rather than lack of elected women local politicians in the Turkish context, such a gendered division of labor in the local governmental structure is important for discussing the decentralization-women's representation problematic in this period.

\section{The 1990s: Local Development and Women as Local Community Builders}

The system of local governance explained above started to fail as the solidarity ties in question lost their legitimacy due to their no longer being functional in resolving the problems of redistribution in the urban space. First, the commodification of these squatter areas has brought the dissolution of the previous non-hostile public opinion about these "disadvantaged" groups due to their having equal standards with the tax payer city dwellers. ${ }^{25}$ Second, there was an increasing social unrest since income distribution was deteriorating and Turkey was ranked among the seven countries that had the worst income distribution. ${ }^{26}$ Third, there was the issue of forced migration. However, the new immigrants did not have a chance to get into free housing in the squatter areas due to commodification of the squatter houses. 
After the 1990s, waves of Kurdish migrants from Southeastern Anatolia immigrated to the big cities for security reasons. ${ }^{27}$ The previous solidarity groups based on hometown were no longer available for the newcomers due to the changing socio-spatial context of gecekondu settlements. The legalization of gecekondu areas turned them into "gated communities" of their own since they were no longer available to the new migrants as flexible solutions. It is in this period when informal networks based on kinship or co-locality (hemsehri) ties could no longer serve as social integration and social reproduction mechanisms. In other words, "the increasing competition for urban resources affected the nature of solidarity networks of migrants." 28 Thus, allying with these groups was no more functional for dealing with the problems of social inclusion and there was need for a new form of planning the provision of social welfare in the urban context.

The worsening of income distribution brought the "protection of social peace"29 into the agenda of local governments again. The previous local governmental regime was blamed for its corrupt and clientelist measures for the purposes of increasing its votes. Thus, the local governments of the post-1990s' Turkey can be analyzed in terms of the adaptation of a new mode of organization and discourse to resolve the emergent crisis of social reproduction and inclusion.

First, new national and international actors started being involved in the reform period. The European Chart of Local Self Government was signed in 1992 and came into force in $1993 .{ }^{30}$ Bank of Cities (Iller Bankast), the institution providing low-interest credits for municipalities, was no longer available for local governmental expenditures due to their high debts. The World Bank instead was one of the important actors resorted to for credit in 1994. Also, Turkish Industry and Business Association (Türk Sanayicileri ve Issadamları Derneği) prepared a local government reform suggestion program. Thus, in the context of the 1990s, local entrepreneurs, professional associations and international entities started to become important local actors and a new mode of cooperation among these actors started to take place. In other words, "there was a new allocation scheme for the responsibilities of public, private, voluntary and household groups and new programs of action through cooperation among these groups." ${ }^{31}$

The new discourse of local development and competitive localities started to frame the resource-generation activities of the local governments. The new local governance strategy, referred to as the second phase of neoliberal urban governance, ${ }^{32}$ consisted of the invention of the locality itself as a communal actor that would bring new basis of cooperation among various groups and a new model of economic development through the local culture and identities. The mode of accumulation was mediated particularly through the networking of international organizations, business associations, voluntary associations and local governments. The main term that functioned as the basis of cooperation in this period was "local capital" and "community empowerment," meaning the mobilization of various social networking ties and alliances at the local level. This period fits into what Nalbandian describes as the increasing community building roles and responsibilities of the local government managers. ${ }^{33}$ 
In terms of the social inclusion model within this new local development strategy, the provision of social welfare under the local development paradigm consisted of both the mobilization and the redistribution of local resources through a cooperative process. The new local actors consisted of "philanthropists and NGOs in the provision of social care and assistance and microcredit schemes to foster entrepreneurship among the poor promoted by international organizations such as the World Bank." 34 This new discourse of locality and local capacity building through the cooperation of various local actors provided a different form of relationship between local community and local politicians. The fractured nature of the previous regime that consisted of various solidarity groups started to be replaced by a more centralized version of solidarity that consisted of cooperation of various groups for the well-being of the "locality."

Social inclusion and redistribution became the responsibility of this local community itself as a whole under this new strategy of development. The local governments became institutions that mediated the relations of social assistance. In other words, as White indicates "it is important to remember that people involved in local network politics perceive themselves as practicing community, not just doing politics." ${ }^{, 35}$ In the decentralization reform programs, there was a shift of meaning of hemsehri from the town of origin to the people living in the same neighborhood. In this period, rather than the "representation" of solidarity groups in the local politics through the clientelist ties with the local politicians, the arena of local politics itself and the way it was practiced started to imitate the networking styles of these solidarity groups. In other words, the subject of local politics becomes

\begin{abstract}
Acknowledging the role of cultural norms in political mobilizing rather than simply conducting business as usual, engaging in top-down campaigning and bidding for local loyalties by establishing themselves as patrons or allying themselves with local patrons who are then expected to deliver the votes of their clients. $^{36}$
\end{abstract}

The very practice of local politics started to change its hierarchical form and the relationship between the local politicians and the constituency started to get more horizontal and "intimate." The local politicians were expected to be "one of them." Local politicians were expected to "be with them in good as well as bad days by participating in the organization of the weddings and circumcision ceremonies, as well as visiting the sick and elderly." 37 Databases were prepared by the municipalities in order to keep the records of the needs of the people in order "to match the potential voters with the most appropriate party workers, for example, dispatching to newly arrived urban migrant party workers from their town or village of origin." 38 Thus, unlike the previous regime, it was the local governmental offices that brought people from the same hometown together and kept these informal relations alive as well as developing their interaction with other local initiatives targeting similar purposes. 
When these characteristics of the local governments in this context are taken into account, the issue of women's political participation at the local level can be read in terms of the changing gendered dynamics of cooperation between the local politicians and the constituencies. As discussed above, the task of making everyone feel a sense of belonging and responsibility in the economic, social and cultural development of the locality was managed in a gendered manner. Women started to take part in the institutions of local politics, especially at the political party level. Under these circumstances, local governments recruited women for building community-like ties with the constituency. Women branches of the political parties were present in the informal associational activities such as "sewing groups, religious meetings, community centers and women's visiting days (gün)." "39 Since such practice of politics fits into the behavioral repertoire of women, this new regime of municipal management compensated for its lack of political capital. Thus, women's participation in local politics during this period should not be discussed in isolation from the overall regime of governing the city.

Women were active in local politics not as elected local politicians but as "nerve cells" of "local identity" constructed as a strategy to deal with the challenges of social inclusion. However, their participation was limited to women branches of the political parties. In other words, "Although playing a crucial role in mobilizing the constituency, women have been systematically excluded from decision-making mechanisms of their party and their activities have been confined to separate auxiliary organizations called Women's Branches." 40 Thus, the strategy of the local government in this period was gendered not only in terms of the role played in reproducing the local ties but also in terms of women's exclusion from decision-making mechanisms. Thus, “informal activism and formal leadership were gender-segregated fields" ${ }^{\prime 1}$ of local politics of that period. The inclusion of new local actors through decentralization measures did not lead to plurality and increased democratic participation. Rather, the construction of "local" identity as a resource for development brought mobilization of resources for the development of the locality as a whole. The local governments became responsible for managing the community as an organic entity. Women's participation in that context was again reduced to overfeminized roles that functioned as sensitive receptors of social needs that sent the input to local governmental centers.

\section{4 and Beyond: "Urban Regeneration" and Women as Upgraders of Locality}

In 2001, the Turkish economy faced one of the most severe economic crises in its history. This brought along important economic measures. As part of these measures, a new legislation about local governments was introduced with the 2004 reform package, attributing new roles on economic and social development of the city to local governments. The economic program that was initiated by the "globalizationoriented urban coalitions" briefly consisted of "gentrifying the city to please the tourist gaze, accelerating deindustrialization, expulsion of manufacturing while promoting service-sector investments." 42 
According to these new reforms, for the first time, gecekondu construction was criminalized and the municipalities were authorized with the implementation of the transformation project of these urban lands. ${ }^{43}$ The officials were also authorized to develop regeneration plans for the historical zones and with the right to restore the historical remains. The municipalities were given the authority to gentrify the ghettoized and dysfunctional areas as well as protecting the natural and cultural heritage of the region. Thus, after the decentralization programs, transformation of the city became an important municipality agenda. The urban space became an arena of projects on "Highly convincing nature centers, hotels, offices, recreational areas and marinas.",44

With the urban land becoming vital for entrepreneurial activities and for the attraction of foreign tourists and investors, the gecekondu land came into the agenda of local governments again. In accordance with the new model of investing on urban land, the gecekondu dwellers were to move to the new units and expected to pay the difference between the cost of these units and the exchange value of the land of their gecekondu. In addition to the economic development of the city, the local governments were given important roles for the "social development" of the city dwellers. Critical posts in social services that used to be the responsibility of the central state were transferred to local governments.

According to this reform package, "taking into account local preferences, health, educational, cultural, social assistance related, tourism, environmental, agricultural, stock-breeding, construction and transportation services will be provided at provincial level." 45 The metropolitan municipalities were given the responsibility of opening centers to serve the social and cultural needs of children and the youth, as well as dealing with the health, education and social needs of the disadvantaged groups such as the elderly, disabled and poor. The municipalities were responsible for creating Counseling Boards to develop policies on empowering children, the disabled and women. ${ }^{46}$ Within the same context, the local governments were responsible for creating social service facilities as well as opening vocational schools for developing professional skills of especially disadvantaged groups and increasing employment. In the relevant policy documents, these social-service centers were framed as places where "self-dependent, productive individuals are raised for the development of the society and the family." ${ }^{47}$ Hence, it was not only the city space that became the subject of "upgrading" but also the personal development of city dwellers themselves.

The assumption was that "poor households do not invest enough in their human capital, and are thus caught in a vicious cycle of intergenerational transmission of poverty, with children dropping out of school and destined to suffer the long-term effects of deprivation." 48 Thus, according to the new formulation of the social inclusion program, the dwellers of gecekondu, framed as "spaces of decay" or "distressed areas," were victims of their disadvantaged conditions. Thus, the new mode of local governance was based more on "transformation" or eradication of the previous forms of networking with the constituency, referred to as new localism or new public management. 
In the previous strategies discussed, informal ties and reciprocal relations among the "disadvantageous" groups were either affirmed or were to be rehabilitated. However, the latest reform program defined these relations as dysfunctional, unsustainable and serving for the reproduction of poverty. Empowerment, upgrading and performance were key paradigms that formed the basis of this new regime of urban governance. The main issue was not helping or assisting local groups in the provision of daily needs but making them more productive and efficient through investing in their "human capital" to make sure that they could provide these needs themselves. The target of empowerment was "the poor and the disadvantaged should result in their gaining more voice and presence in decision-making arenas and hence they are no longer 'beneficiaries' or 'clients of the state' but empowered, active citizens capable of formulating their own needs." 49 Thus, community-based development and social inclusion strategies were replaced by individual performance and efficiency-based economic and social policies. As Ayata and Tütüncü indicate, the gendered implications of such stress on individual empowerment can be followed from the policy measures which stress that "Not only because women make up half of our population, but also because they are primarily effective for raising healthy generations, they should be considered as individuals before everything else."50

During this period, women's participation in decision-making bodies became an important agenda. Political parties arranged education programs to increase female political literacy as well as developing leadership skills. Education was underlined as an important step for women politicians. Eventually, these educated women started to be nominated and elected for positions within decision-making mechanisms of local governments. Although, the number of women local politicians is very low in the literature, especially in the metropolitan local governments, the increasing trend in the number of women local politicians is significant and might be analyzed as a change of gender regime in the governing structure of local politics.

For the purposes of analyzing the implication of this increasing number of female local politicians, it is necessary to follow the previous parallel analysis of entrepreneurial and social inclusion policies of the decentralization reforms. As discussed above, the main term that functioned as the basis of social inclusion programs of this period was empowerment of the socially excluded disadvantaged and vulnerable groups. Women were among the most important "disadvantaged" groups. Therefore, first it is possible to argue that women local politicians served as important role models through their successful self-empowerment stories. Second, in order to discuss whether increase in the number of female local politicians means increased representation of women in general, it might be helpful to analyze how they practiced their "policy agency."

The term "women's policy agency" 51 refers to the limits and possibilities of the agency of women in elected political offices. First, in the policy structure, the content of these services as well as the ways these policies come into practice, female constituencies are among the main recipients of social assistance as a disadvantaged group. Second, when the programs developed particularly for women as a disadvantaged group in need of developing their individual skills and performance are examined, the areas in which they are empowered are reduced to their roles as 
mothers and wives. As indicated above, municipalities were responsible for opening centers that women could consult with in order to solve their problems.

These centers were mostly named as women and family centers, centers for women's and children's health, and centers for the education of women and family. Women's health centers were mostly referred to as centers of women and family, and the seminars and education programs consisted of topics on motherchild and husband-wife relations. At these centers, women were given education programs before and after marriage about how to accomplish communication among family members, how to manage arguments within the household and how to raise good children. Thus, the services mostly targeted reproduction of the family.

The municipalities also opened centers for supporting female employment. Yet similar to the discourse of other policy agendas, female employment was usually stressed not in terms of women's own goods as individuals but as a support to the household income. The mother's role and responsibility in education and wellbeing of their children were highly stressed. A city's renewal was equated to the regeneration of women's life styles. The social inclusion discourses on tidying up the city space, empowering the disadvantaged to turn them into self-dependent residents and how this was symbolized through the transformation of their home, were important for an analysis of the roles set for female local politicians.

Their new role assigned to mothers for raising "the mothers of the future" brought along the translation of feminized labor at home to the way local politics was structured and performed. Under these conditions, the gendered division of labor within the house started to become a resource that women could translate into capital. In the literature, women being overloaded with their responsibilities at home has been emphasized as an impediment to their taking active part in local governments. However, these discursive parallels between the gendered roles at home and at the city, and how they construct the gendered identities within the local political institutions, might be read as a need for different analytical tools to analyze the interaction between the gender roles in the institutions of politics and in other social institutions.

Within the social inclusion strategy of the new economic program of local governments in Turkey, the policy agency of women was reduced to the activities related to empowering the disadvantaged groups, among which women were also included. The content of these programs were "shaped first and foremost in terms of the familial sphere" 52 and female empowerment was presented as a critical step in the empowerment and upgrading of the household. Thus, while the success stories of female local politicians as good mothers and wives with professional careers were used as a symbol of this upgraded face of the city, their policy agenda was limited by the predetermined gender roles within the overall local governance strategy.

\section{Conclusion}

In this study, three periods of decentralization reforms after 1980 in Turkey have been discussed in terms of strategies of social reproduction as well as main actors that local 


\section{S. Yaraş}

governments have allied with for the purposes of social inclusion. Within the policy structures of these three periods, the question of social inclusion was framed as reproduction of solidarity groupings, building local community as a self-help group itself and regeneration of the disadvantageous groups. These are all over-feminized strategies in the sense that they attribute certain roles to women, limiting not only the possibility for their taking active roles in the decision-making bodies of these institutions but also their policy agency even when they succeed in entering them.

Thus, these three regimes of urban governance and the particular gender characteristics of each of these regimes can be discussed in terms of the challenges they introduce to the theoretical and methodological discussions about the question of women's representation at the local level. Decentralization as an administrative reform program in different time periods in Turkey was based on a corporate regime that brought together various actors for the purpose of local development. Thus, rather than increased representation, accountability and democracy as stressed in the idealized definition of decentralization, development continued to be the main driving force of decentralization. The local governments functioned as the institutions that brought together different local actors at different periods, serving a single purpose rather than as institutions where conflicting interests are represented.

Representation of women under such structures is reduced to women fulfilling the roles attributed to them in the strategy of local development in a given context. Thus, rather than attributing an emancipatory role to local governments as discussed in the idealizing approaches to decentralization, their roles and legitimacy structures in a given time and space should be discussed in detail. Not every woman has equal chances to participate or to be "represented" in these institutions and hence certain gendered identities, interactions and discourses start to get more dominant or hegemonic. What Lovenduski names as "women's policy agency," 53 referring to the limits and possibilities of the agency of women in elected political offices, is itself conditioned by the structure of these offices at that time and space. This recruitment of women for certain purposes either as elected or as non-elected participants might be conceptualized as "over-feminized" local governance in the sense that their representation has been reduced to their fulfilling certain fixed gender roles for serving their community, locality or family.

\section{Notes}

1. Beall, "Decentralizing Government and Decentering Gender," 254-76; Pierre, "Comparative Urban Governance Uncovering Complex Causalities," 446-62; and Kearns, "Active Citizenship and Local Governance," 155-75.

2. Alkan, "Gendered Structures of Local Politics in Turkey," 31.

3. Devas and Grant, "Local Government Decision Making, Citizen Participation and Local Accountability," 307-16; Krishna, "Partnerships Between Local Governments and Community-Based Organisations," 361-71; and Ebrahim, "Accountability in Practice," 813-29.

4. Manor, Political Economy of Democratic Decentralization, vii.

5. Some relevant studies on the cases of Japan, UK, Continental Europe, Canada, Mexico and South Africa are as follows: Peng, "Social Care in Crisis," 411-43; Lewis, "Gender and Welfare State 
Change," 331-57; Luccisano and Macdonald, "Neo-liberalism, Semi-clientelism and the Politics of Scale," 1-27; Beall, "Decentralizing Government and Decentering Gender," 253-76.

6. Brenner, "Global Cities, Glocal States," 1-37; McGuirk and MacLaran, "Changing Approaches to Urban Planning," 437-57; Yu, Zhang, and Yin, "Entrepreneurial Inclination of China's City Marketing," 608-12; and Quilley, "Manchester First," 601-15.

7. Halford and Savage, "Restructuring Organisations, Changing People," 100.

8. Mackay, “'Thick' Conceptions of Substantive Representation," 125.

9. Although cross-country comparison is out of the methodological limits of this study, some examples about how socioeconomic gender codes in a given context interact with the processes of decentralization in different countries should be listed here: Halford and Savage, "Restructuring Organisations," 97-122; Bakshi et al., "Gender, Race, and Class in the Local Welfare State," 1539-54; Mattingly, "Home and the World," 370-86; and MacLeavy, "Engendering New Labour's Workfarist Regime," 721-43.

10. Buğra, "Immoral Economy of Housing in Turkey," 313.

11. Alkan, Yerel Yönetimler ve Cinsiyet, 6.

12. Roy, "Why India Cannot Plan Its Cities," 85.

13. Danielson and Keleş, Politics of Rapid Urbanization, 39.

14. Kıray, Kentleşme Yazıları, 21.

15. Karpat, The Gecekondu, 9.

16. Bayraktar, "Turkish Municipalities," 21.

17. Öncï, "Politics of the Urban Land Market in Turkey," 44.

18. Erkip, "Global Transformations Versus Local Dynamics in Istanbul," 372.

19. Baslevent and Dayoglu, "Effect of Squatter Housing," 33.

20. Hersant and Toumarkine, "Hometown Organisations in Turkey," 17.

21. White, Para ile Akraba, 33.

22. Işık and Pınarcıŏlu, "Sultanbeyli Üzerine Notlar," 47.

23. Eroğlu, Beyond the Resources of Poverty, 12.

24. Kalaycioğlu, "Dynamics of Poverty in Turkey," 226.

25. Buğra, "Immoral Economy of Housing in Turkey," 313.

26. Ahmad, Modern Türkiye'nin Oluşumu, 285.

27. Bartu-Candan and Kolluoğlu, "Emerging Spaces of Neoliberalism," 7.

28. Murakami, Constructing Female Subject, 7.

29. Cizre-Sakallioglu and Yeldan, "Politics, Society and Financial Liberalization," 482.

30. Ministry of Interior, General Directorate of Local Authorities, "Local Governments in Turkey."

31. Uzun, "Globalization and Urban Governance in Istanbul," 128.

32. Doğan, "Neo-Liberal Belediyeciliğin Çelik Zırhı," 5.

33. Nalbandian, "Facilitating Community, Enabling Democracy," 187.

34. Buğra and Yakut-Cakar, "Structural Change," 531.

35. White, Islamist Mobilization in Turkey, 22.

36. Ibid., 28.

37. Ayata and Tütüncü, "Party Politics of the AKP," 369.

38. Jenkins, "Muslim Democrats in Turkey?," 63.

39. Secor, "Toward a Feminist Counter-Geopolitics," 205.

40. Çavdar, "Islamist Moderation and the Resilience of Gender," 341.

41. White, Islamist Mobilization in Turkey, 214.

42. Keyder, "Globalization and Social Exclusion in Istanbul," 128.

43. Kuyucu and Ünsal, "Urban Transformation' as State-Led Property Transfer," 1484.

44. İslam, "Current Urban Discourse," 61.

45. Local Administration Reform Programme, "Policy Documents."

46. Şengül, "Yerel Devlet Sorunu Ve Yerel Devletin Dönüşümünde Yeni Eğilimler," 206.

47. Bayraktar, Makbul Anneler Müstakbel Vatandaşlar, 215.

48. Molyneux, "Mothers at the Service of the New Poverty Agenda," 433. 


\section{S. Yaraş}

49. Ibid., 429.

50. Ayata and Tütüncü, "Party Politics of the AKP," 378.

51. Lovenduski, Feminizing Politics, 106.

52. Coşar and Yeğenoğlu, "New Grounds for Patriarchy in Turkey," 557.

53. Lovenduski, Feminizing Politics, 106.

\section{Notes on Contributor}

Sezen Yaraş is a $\mathrm{PhD}$ candidate of political science and public administration from Bilkent University in Ankara, Turkey. She has had research stays at the University of Chicago, USA, as a Fulbright Grantee. She had participated as a researcher in the research projects of United Nations Development Programme, Turkish Ministry of Development and the Scientific and Technological Research Council of Turkey. Her research interests cover gender and politics, women's representation at local governments, gender and social policy and feminist research methodologies.

\section{Bibliography}

Ahmad, Feruz. Modern Türkiye’nin Oluşumu [The Making of Modern Turkey]. İstanbul: Sarmal Yayınevi, 1995.

Alkan, Ayten. "Gendered Structures of Local Politics in Turkey." Digest of Middle East Studies 18, no. 1 (2009): 31-56.

Alkan, Ayten. Yerel Yönetimler ve Cinsiyet. Ankara: Dipnot Yayınları, 2005.

Ayata, Ayşe Güneş, and Fatma Tütüncü. "Party Politics of the AKP (2002-2007) and the Predicaments of Women at the Intersection of the Westernist, Islamist and Feminist Discourses in Turkey." British Journal of Middle Eastern Studies 35, no. 3 (2008): 363-384.

Bakshi, Parminder, Mark Goodwin, Joe Painter, and Alan Southern. "Gender, Race, and Class in the Local Welfare State: Moving Beyond Regulation Theory in Analysing the Transition From Fordism." Environment and Planning A 27 (1995): 1539-1539.

Bartu-Candan, Ayfer, and Biray Kolluoğlu. "Emerging Spaces of Neoliberalism: A Gated Town and a Public Housing Project in Istanbul." New Perspectives on Turkey 39 (2008): 5-46.

Başlevent, Cem, and Meltem Dayoğlu. "The Effect of Squatter Housing on Income Distribution in Urban Turkey." Urban Studies 42, no. 1 (2005): 31-45.

Bayraktar, Sevi. Makbul Anneler Müstakbel Vatandaşlar: Neoliberal Beden Politikalarında Annelik. Ankara: AyiziKitap, 2011.

Bayraktar, Ulaş. "Turkish Municipalities: Reconsidering Local Democracy Beyond Administrative Autonomy." European Journal of Turkish Studies. Social Sciences on Contemporary Turkey (2007): 1-29. Accessed February 11, 2013. http://ejts.revues.org/1103

Beall, Jo. "Decentralizing Government and Decentering Gender: Lessons from Local Government Reform in South Africa." Politics and Society 33, no. 2 (2005): 254-276.

Brenner, Neil. "Global Cities, Glocal States: Global City Formation and State Territorial Restructuring in Contemporary Europe." Review of International Political Economy 5, no. 1 (1998): 1-37.

Buğra, Ayşe. "The Immoral Economy of Housing in Turkey." International Journal of Urban and Regional Research 22, no. 2 (1998): 303-307.

Buğra, Ayşe, and Burcu Yakut-Cakar. "Structural Change, the Social Policy Environment and Female Employment in Turkey." Development and Change 41, no. 3 (2010): 517-538.

Çavdar, Gamze. "Islamist Moderation and the Resilience of Gender: Turkey's Persistent Paradox." Totalitarian Movements and Political Religions 11, nos. 3-4 (2010): 341-357.

Cizre-Sakallığlu, Ümit, and Erinç Yeldan. "Politics, Society and Financial Liberalization: Turkey in the 1990s." Development and Change 31, no. 2 (2000): 481-508.

Coşar, Simten, and Metin Yeğenoğlu. "New Grounds for Patriarchy in Turkey? Gender Policy in the Age of AKP.” South European Society and Politics 16, no. 4 (2011): 555-573. 
Danielson, Michael N., and Ruşen Keleş. The Politics of Rapid Urbanization: Government and Growth in Modern Turkey. New York: Holmes \& Meier, 1985.

Devas, Nick, and Ursula Grant. "Local Government Decision-Making-Citizen Participation and Local Accountability: Some Evidence from Kenya and Uganda." Public Administration and Development 23, no. 4 (2003): 307-316.

Doğan, Ali Ekber. "Neo-Liberal Belediyeciliğin Çelik Zırhı: Yerel Kalkınma.” Mülkiye Dergisi XXIX, no. 246 (2005): 77-88.

Ebrahim, Alnoor. "Accountability in Practice: Mechanisms for NGOs." World Development 31, no. 5 (2003): 813-829.

Erkip, Feyzan. "Global Transformations Versus Local Dynamics in Istanbul: Planning in a Fragmented Metropolis." Cities 17, no. 5 (2000): 371-377.

Eroğlu, Şebnem. Beyond the Resources of Poverty: Gecekondu Living in the Turkish Capital. Burlington, VT: Ashgate, 2011.

Halford, Susan, and Mike Savage. "Restructuring Organisations, Changing People: Gender and Restructuring in Banking and Local Government." Work, Employment \& Society 9, no. 1 (1995): 97-122.

Hersant, Jeanne, and Alexandre Toumarkine. "Hometown Organisations in Turkey: An Overview." European Journal of Turkish Studies. Social Sciences on Contemporary Turkey 2 (2009): 1-24.

Işık, Oğuz, and Melih Pınarcıoğlu. "Sultanbeyli Notları.” Birikim 123 (1999): 47-53.

İslam, Tolga. "Current Urban Discourse, Urban Transformation and Gentrification in İstanbul." Architectural Design 80, no. 1 (2010): 58-63.

Jenkins, Gareth. "Muslim Democrats in Turkey?" Survival 45, no. 1 (2003): 45-66.

Kalaycioğlu, Sibel. "Dynamics of Poverty in Turkey: Gender, Rural/Urban Poverty, Social Networks and Reciprocal Survival Strategies." In Poverty and Social Deprivation in the Mediterranean: Trends, Policies and Welfare Prospects in the New Millennium, edited by Maria Petmesidou and Christos Papatheodorou, 218-247. New York: Zed Books, 2006.

Karpat, Kemal H. The Gecekondu: Rural Migration and Urbanization in Turkey. Cambridge: Cambridge University Press, 1976.

Kearns, Ade. "Active Citizenship and Local Governance: Political and Geographical Dimensions." Political Geography 14, no. 2 (1995): 155-175.

Keyder, Çaglar. "Globalization and Social Exclusion in Istanbul." International Journal of Urban and Regional Research 29, no. 1 (2005): 124-134.

Kıray, Mübeccel Belik. Kentleşme yazıları. İstanbul: Bağlam Yayıncılık, 2007.

Krishna, Anirudt. "Partnerships Between Local Governments and Community-Based Organisations: Exploring the Scope for Synergy." Public Administration and Development 23, no. 4 (2003): $361-371$.

Kuyucu, Tuna, and Özlem Ünsal. “'Urban Transformation' as State-Led Property Transfer: An Analysis of Two Cases of Urban Renewal in Istanbul.” Urban Studies 47, no. 7 (2010): 1479-1499.

Lewis, Jane. "Gender and Welfare State Change." European Societies 4, no. 4 (2002): 331-357.

Local Administration Reform Programme. "Policy Documents: Government Programme." Accessed March 3, 2013. http://www.lar.gov.tr/policydocs.html\#

Lovenduski, Joni. Feminizing Politics. Cambridge: Polity Press, 2005.

Luccisano, Lucy, and Laura Macdonald. "Neo-Liberalism, Semi-clientelism and the Politics of Scale in Mexican Anti-poverty Policies.” World Political Science Review 8, no. 1 (2012): 1-27.

Mackay, Fiona. “Thick' Conceptions of Substantive Representation: Women, Gender and Political Institutions." Representation 44, no. 2 (2008): 125-139.

MacLeavy, Julie. "Engendering New Labour's Workfarist Regime: Exploring the Intersection of Welfare State Restructuring and Labour Market Policies in the UK." Gender, Place and Culture 14, no. 6 (2007): 721-743.

Manor, James. The Political Economy of Democratic Decentralization. Washington, DC: World Bank, 1999. 


\section{S. Yaraş}

Mattingly, Doreen J. "The Home and the World: Domestic Service and International Networks of Caring Labor." Annals of the Association of American Geographers 91, no. 2 (2001): 370-386.

McGuirk, Pauline M., and Andrew MacLaran. "Changing Approaches to Urban Planning in an 'Entrepreneurial City': The Case of Dublin.” European Planning Studies 9, no. 4 (2001): 437-457.

Ministry of Interior, General Directorate of Local Authorities. "Local Governments in Turkey." Accessed January 22, 2013. http://www.migm.gov.tr/en/PDF/GeneralInformation.pdf

Molyneux, Maxine. "Mothers at the Service of the New Poverty Agenda: Progresa/Oportunidades, Mexico's Conditional Transfer Programme." Social Policy \& Administration 40, no. 4 (2006): $425-449$.

Murakami, Kaoru. Constructing Female Subject: Narratives on Family and Life Security among the Urban Poor in Turkey. Chiba: Japan External Trade Organization (JETRO) Institute of Developing Economies Publications, 2009.

Nalbandian, John. "Facilitating Community, Enabling Democracy: New Roles for Local Government Managers." Public Administration Review 59, no. 3 (1999): 187-197.

Öncü, Ayşe. "The Politics of the Urban Land Market in Turkey: 1950-1980." International Journal of Urban and Regional Research 12, no. 1 (1988): 38-64.

Peng, Ito. "Social Care in Crisis: Gender, Demography, and Welfare State Restructuring In Japan." Social Politics: International Studies in Gender, State \& Society 9, no. 3 (2002): 411-443.

Pierre, Jon. "Comparative Urban Governance Uncovering Complex Causalities." Urban Affairs Review 40, no. 4 (2005): 446-462.

Quilley, Stephen. "Manchester First: From Municipal Socialism to the Entrepreneurial City." International Journal of Urban and Regional Research 24, no. 3 (2000): 601-615.

Roy, Ananya. "Why India Cannot Plan Its Cities: Informality, Insurgence and the Idiom of Urbanization." Planning Theory 8, no. 1 (2009): 76-87.

Secor, Anna J. "Toward a Feminist Counter-Geopolitics: Gender, Space and Islamist Politics in Istanbul." Space and Polity 5, no. 3 (2001): 191-211.

Şengül, Tarık. "Yerel Devlet Sorunu ve Yerel Devletin Dönüşümünde Yeni Eğilimler.” Praksis Dergisi 9 (2003): $183-220$.

Uzun, C. Nil. "Globalization and Urban Governance in Istanbul." Journal of Housing and the Built Environment 22, no. 1 (2007): 127-138.

White, Jenny B. Islamist Mobilization in Turkey: A Study in Vernacular Politics. Washington, DC: University of Washington Press, 2011.

White, Jenny. Para ile Akraba: Kentsel Türkiye'de Kadın Emeği [Money Makes Us Relatives: Women's Labor in Urban Turkey]. İstanbul: İletişim Yayınları, 1999.

Yu, Tao, Jing-xiang Zhang, and Jie Yin. "The Entrepreneurial Inclination of China's City Marketing and Its Effect During the Period of Transformation." Economic Geography 4 (2009): 608-612. 